\title{
Perceived Organizational Support sebagai moderator Iklim Organisasi Terhadap Kepuasan Kerja Karyawan
}

\author{
Muhammad Nur Syuhada' \\ Universitas Ahmad Dahlan \\ nur.syuhada@psy.uad.ac.id
}

\begin{abstract}
Abstrak
Penelitian ini bertujuan untuk mengetahui bagaimana pengaruhnya iklim organisasi terhadap kepuasan kerja karyawan, dengan dimoderatori tingginya perceived organizational support. Subjek penelitian berjumlah 74 , dengan teknik pengambilan sampel mengunakan purposive sampling. Data dikumpulkan dengan menggunakan skala iklim organisasi, kepuasan kerja, dan perceived organizational support. Hasil penelitian menunjukkan bahwa perceived organizational support yang dirasakan karyawan merupakan moderator hubungan antara pengaruh iklim organisasi terhadap kepuasan kerja karyawan. Peranan. Perceived organizational support berperan mempengaruhi secara signifikan terhadap iklim organisasi dalam meningkatkan kepuasan kerja karyawan.
\end{abstract}

Kata kunci :iklim organisasi, perceived organizational support, kepuasan kerja

\begin{abstract}
This study aims to determine how the influence of organizational climate on employee job satisfaction, with moderated high perceived organizational support. Research subjects was 74 employee, with a sampling technique using purposive sampling. Data were collected using organizational climate scale, job satisfaction, and perceived organizational support. The results showed that perceived organizational support felt by employees was a moderator of the relationship between the influence of organizational climate on employee job satisfaction. Role perceived organizational support plays a significant influence on organizational climate in increasing employee job satisfaction.
\end{abstract}

Keywords: organization climate, perceived organizational support, work satisfactio

\section{PENDAHULUAN}

Kepuasan karyawan merupakan salah satu kunci pendorong moral dan disiplin serta kinerja karyawan yang akan berpengaruh dalam upaya mewujudkan sasaran perusahaan secara strategis. Kepuasan kerja mencerminkan perasaan tenaga kerja terhadap pekerjaannya, hal ini merupakan dampak dari sikap positif karyawan terhadap pekerjaan dan segala sesuatu yang dihadapi di lingkungan kerjanya (Robbins, 2003). Robbins dan Judge (2014) menyatakan, apabila karyawan tidak merasa adanya pengawasan, prosedur organisasi, atau kebijaksanaan bayaran adil, kepuasan kerja karyawan cenderung menurun secara signifikan. Namun, ketika karyawan merasa bahwa proses dan hasil-hasil organisasional tersebut adil, berkembanglah rasa percaya diri. Selain itu, ketika karyawan mempercayai pemberi kerja, karyawan lebih bersedia untuk terlibat secara sukarela dalam perilaku-perilaku yang melebihi persyaratan kerja formalnya. Karyawan yang puas tampaknya akan lebih mungkin berbicara positif tentang organisasi, membantu orang lain, dan jauh melebihi harapan yang normal dalam pekerjaan. Lagi pula, karyawan yang puas mungkin menjadi lebih bangga melebihi tuntutan tugas karena ingin membalas pengalaman positif (Robbins, 2003).

Dengan kata lain, kepuasan karyawan dapat dilihat dari bagaimana karyawan 
memberikan kontribusi positif pada organisasi. Kepuasan sendiri secara ringkas di sampaikan oleh Nurendra dan Saraswati (2018) perasaan menyenangkan yang dirasakan individu terhadap pekerjaannya. Kondisi ini tentu baru akan di dapatkan ketika individu berada pada lingkungan dan kondisi yang nyaman, atau di kenal dengan istilah iklim organisasi. Wibisono (2011) individu dengan kepuasan kerja yang baik bergantung pada iklim yang di ciptakan di tempat kerja. Iklim organisasi perlu berjalan dengan kondusif untuk memberi kenyamanan karyawan dalam berkerja, loyal dan tetap bertahan pada organisasi (Saputra \& Rahardjo, 2013).

Davis (2001) mengemukakan pengertian iklim organisasi sebagai "Thehuman environment within an organization's employees do their work", hal ini diartikan bahwa iklim organisasi itu adalah yang menyangkut semua lingkungan yang ada atau yang dihadapi oleh manusia di dalam suatu organisasi tempat mereka melaksanakan pekerjaannya. Iklim organisasi berpengaruh sangat signifikan terhadap kepuasan kerja karyawan, yang berarti semakin baik iklim organisasi, maka akan semakin tinggi kepuasan kerja karyawan.(Etty Susanty, 2012; Idrus, 2006; Runtu \& Widyarini, 2009; Surachim, 2008). Hal ini dikarenakan iklim organisasi diperlukan untuk menciptakan tempat kerja yang positif dari segi perilaku maupun sikap(Dirks \& Ferrin, 2002). Gershon et al., (2007) menyimpulkan bahwa memperbaiki iklim organisasi kemungkinan dapat meningkatkan kinerja.

Iklim organisasi akan berjumlah sama dengan individu yang ada di dalam perusahaan (Idrus, 2006). Kondisi iklim yang baik dan kondusif, menurut Idrus (2006) tidak bersifat absolut namun bergantung pada bagaimana persepsi dan kondisi yang dirasakan karyawan. Persepsi ini dapat di artikan sebagai ancaman namun juga dukungan. Dengan kata lain, hubungan antara iklim organisasi dan kepuasan kerja bergantung pula pada bagaimana individu memperceived organizational support dari karyawan. Mengingat kepuasan kerja juga dipengaruhi oleh faktorfaktor pekerjaan yang menantang, imbalan yang adil, kondisi kerja yang mendukung dan dukungan rekan sekerja serta supervise (Robbins \& Timothy A. Judge, 2014).Dukungan dari organisasi ini di persepsi oleh karyawan dalam bentuk Perceved organizational support. Penelitian menunjukkan bahwa perceived organizational support dapat memberikan pengaruh pada kepuasan kerja individu(Puspaatmaja \& Aryana Satrya, 2016; Sandra, Alfian, \& N, 2015).

Berdasarkan penjelasan diatas, maka permasalahan penelitian ini yang diangkat adalah pengaruh iklim organisasi terhadap kepuasan kerja karyawan dengan perceived organizational support karyawan sebagai variabel moderator. Penelitian ini bertujuan untuk mengetahui bagaimana pengaruhnya iklim organisasi terhadap kepuasan kerja karyawan, apakah jika dimoderatori dengan tingginya perceived organizational support karyawan akan meningkatkan kepuasan kerja karyawan.

\section{METODE}

Metode pengumpulan data dalam penelitian ini menggunakan skala iklim organisasi, kepuasan kerja, dan perceived organizational support. Skala menggunakan model Likert dengan rentang 1 (sangat tidak setuju) sampai dengan 5 (sangat setuju). Subjek penelitian adalah karyawan PT.X di Yogyakarta yang berjumlah 74 karyawan. Teknik pengambilan sampel menggunakan purposive sampling dengan kriteria subjek minimal telah bekerja selama 6 (enam) bulan.

HASIL

Tabel 1. Hasil uji normalitas Kolmogorov-Smirnov

\begin{tabular}{lccc}
\multicolumn{1}{c}{ Variabel } & Kolmogorov-Smirnov & sig & Keterangan \\
\hline Iklim Organisasi & 0.102 & 0,200 & Normal \\
\hline Kepuasan Kerja & 0,119 & 0,094 & Normal \\
\hline PerceivedOrganizational Support & 0,101 & 0,200 & Normal \\
\hline
\end{tabular}


Berdasarkan uji normalitas dengan Kolmogorov-Smirnov pada tabel 1, diketahui bahwa Iklim organisasi, memiliki nilai KSZ sebesar 0,102 dengan signifikansi 0,200 (p>0,05). Kepuasan Kerja memiliki nilai KSZ sebesar 0,119 dan signifikansi 0,094 ( $p>0,05$ ). Pada variabel Perceived Organizational Support nilai KSZ sebesar 0,101 dan signifikansi 0,200 ( $>0,05)$, dengan demikian seluruh variabel dalam penelitian ini dapat dikatakan berdistribusi normal, dengan $\mathrm{p}>0,05$.

Tabel 1. Hasil uji normalitas Kolmogorov-Smirnov

\begin{tabular}{lccc}
\hline \multicolumn{1}{c}{ Kepuasan kerja } & Linearity & F & Keterangan \\
\hline Iklim Organisasi terhadap kepuasan kerja & 0,000 & 64.27 & Linear \\
\hline POS terhadap Kepuasan Kerja & 0,000 & 96.91 & Linear \\
\hline Iklim Organisasi terhadap POS & 0,000 & 55.72 & Linear \\
\hline
\end{tabular}

Berdasarkan hasil uji linearitas pada tabel 2, iklim organisasi dengan kepuasan kerja, kepuasan kerja dengan perceived organizational support, dan iklim organisasi dengan perceived organizational support, memiliki nilai linearity $0,000(\mathrm{p}<0,05)$ dengan demikian data dapat di katakan linear.

Tabel 3. Hasil uji hipotesis

\begin{tabular}{llclll}
\hline \multicolumn{1}{c}{ Kepuasan kerja } & R & R Square & B & F & sig \\
\hline Iklim Organisasi & $.784^{\mathrm{a}}$ & .614 & 0.614 & 71.68 & 0,00 \\
\hline Iklim Organisasi, POS & $.871^{\mathrm{b}}$ & .758 & 0.144 & 26.25 & 0,00 \\
\hline Iklim Organisasi, POS, Moderator & $.989^{\mathrm{c}}$ & .979 & 0.220 & 444.91 & 0,00
\end{tabular}

Uji hipotesis dilakukan menggunakan analisis berjenjang, di dasarkan pada langkahlangkah yang disampaikan oleh widhi. Berdasarkan data tabel 3. menunjukkan bahwa, Model 1 menggambarkan hubungan ketika Iklim organisasi terhadap kepuasan, sumbangan prediktor sebesar 61,4\%, dengan signifikansi $0,00 \quad(\mathrm{~F}=71.68)$. Artinya iklim organisasi dapat memprediksi kepuasan kerja secara signifikan. Model 2, pada jenjang ini Iklim organisasi tapi ditambahkan POS. POS ternyata juga memprediksi Kepuasan kerja, dengan bukti sumbangan efektif dari $61,4 \%$ menjadi $75,8 \%$ dengan signifikansi $0,00 \quad(\mathrm{~F}=26.253)$. Artinya iklim organisasi dan POS dapat memprediksi Kepuasan Kerja secara signifikan.

Setelah Iklim organisasi dan POS dimasukkan, pada model 3, dimasukkan Moderator (merupakan hasil kali antara POS dan Iklim organisasi). Adanya Moderator disini semakin mampu memprediksi kepuasan kerja dengan baik, dengan sumbangan efektif dari 75,8\% menjadi 97,9\%. Artinya Moderator memberikan andil sebesar 22\%, dengan signifikansi 0,00 $(\mathrm{F}=444.917)$. Dengan demikian disimpulkan bahwa Iklim organisasi dan POS mampu memprediksi kepuasan kerja individu. Selain itu POS juga terbukti menjadi moderator hubungan antara Iklim organisasi dan Kepuasan Kerja, sehingga dengan demikian dapat disimpulkan hipotesa diterima. Semakin tinggi perceived organizational support karyawan, semakin besar peranan iklim organisasi dalam meningkatkan kepuasan kerja karyawan.

Dari model di atas persamaan regresi yang dapat diturunkan adalah sebagai berikut $: \mathrm{Y}=$ $\mathrm{B} 1 \mathrm{X}+\mathrm{B} 2 \mathrm{M}+\mathrm{B} 3 \mathrm{XM}+\mathrm{c}$, maka $\mathrm{Y}=0,413 \mathrm{X}+0,531 \mathrm{M}+0,941 \mathrm{XM}$ (nilai diambil dari nilai coeficien beta). 
Gambar.1 Jalur Moderasi

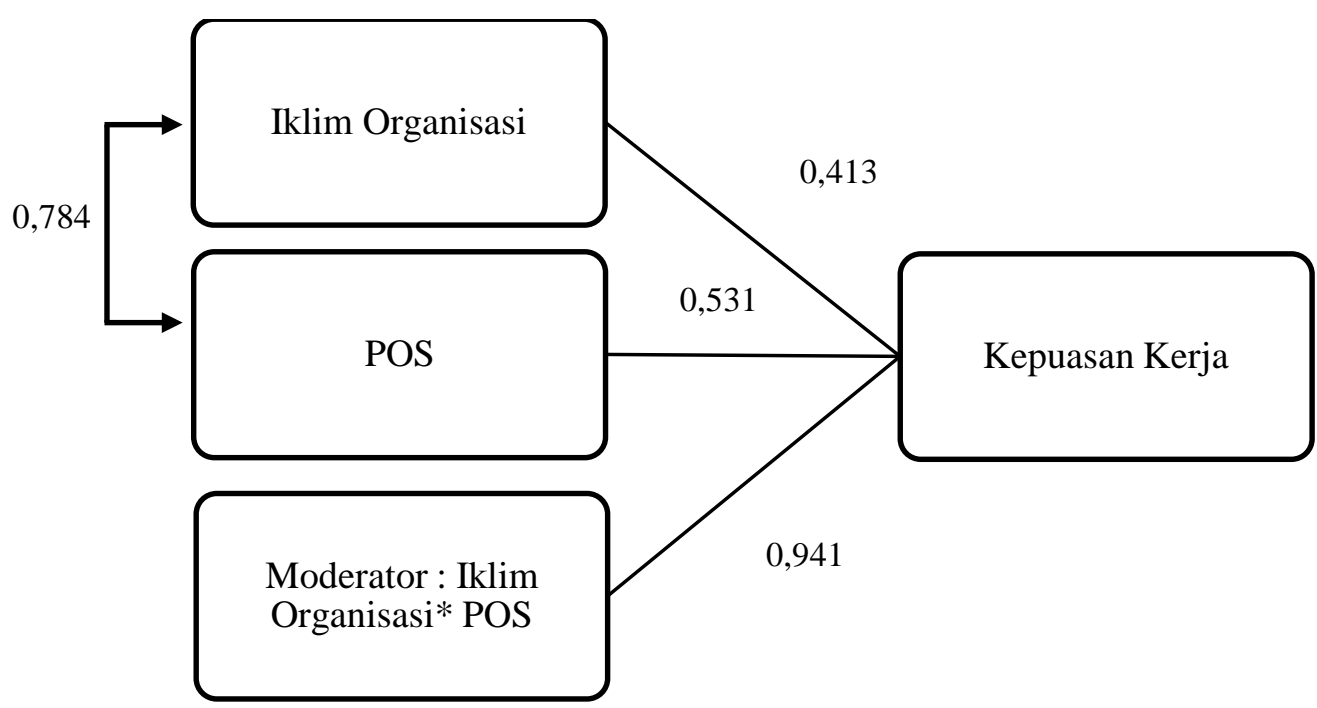

Berdasarkan gambar 1 diatas menunjukkan, dapat diketahui bahwa iklim organisasi dan POS merupakan dua buah variabel eksogen yang satu dengan yang lainnya mempunyai kaitan korelatif. Selain itu, variabel eksogen tersebut secara bersama-sama mempengaruhi variabel endogen kepuasan kerja. Nilai 0.78 pada garis panah antara iklim organisasi dan POS adalah korelasi antara iklim organisasi dengan POS. Nilai korelasi antara iklim organisasi dan POS relatif kuat karena nilai tersebut diatas 0.50 sehingga dapat disimpulkan bahwa kedua variabel tersebut relatif memiliki kesamaan. Nilai beta $=0.413$ adalah koefisien regresi iklim organisasi terhadap Kepuasan Kerja dan nilai beta $=0.531$ adalah koefisien regresi POS terhadap kepuasan kerja. Nilai beta $=0.91$ adalah koefisien regresi iklim organisasi dan POS sebagai moderator terhadap kepuasan kerja. Apabila dilihat dari bobot koefisien estimasinya maka dapat dijelaskan bahwa pengaruh POS terhadap kepuasan kerja relatif lebih kuat dibandingkan pengaruh Iklim Organisasi terhadap kepuasan Kerja. Dan ketika POS memoderatori iklim organisasi terhadap kepuasan kerja menjadikan pengaruhnya lebih kuat terhadap kepuasan kerja. Sehingga dapat dipahami POS dapat memprediksi untuk meningkatkan pengaruh iklim organisasi terhadap kepuasan kerja.

\section{PEMBAHASAN}

Berdasarkan hasil penelitian menunjukkan bahwa iklim organisasi positif dengan perceived organizational support karyawan yang rendah ataupun tinggi tetap dapat memprediksi kepuasan kerja karyawan dengan baik. Dengan kata lain POS dapat menjadi moderator hubungan antara iklim organisasi dengan kepuasan kerja. Hal ini di dukung oleh pernyataan Idrus (2006) bahwa iklim organisasi di pengaruhi penilaian atau persepsi yang subjektif dari individu dan kemudian mempengaruhi kepuasan kerja.

Dalam penelitian ini juga diketahui ada hubungan antara iklim organisasi dan perceived organizational support terhadap kepuasan kerja. Temuan ini didukung oleh beberapa temuan sebelumnya bahwa baik iklim organisasi maupun dukungan organisasi dapat mempengaruhi kepuasan kerja individu (Ariyani, 2012; Etty Susanty, 2012; Idrus, 2006; Lagonah, Pio, \& Kaunang, 2013; Puspaatmaja \& Aryana Satrya, 2016; R.Yudhi Satria R.A., 2005; Saputra \& Rahardjo, 2013; Surachim, 2008). Penelitian Surachim (2008), menunjukkan bahwa iklim organisasi berpengaruh sangat signifikan terhadap kepuasan kerja karyawan, yang berarti 
semakin baik iklim organisasi, maka akan semakin tinggi pula kepuasan kerja karyawan.

Lingkungan kerja yang nyaman dapat memberikan kontribusi positif pada prestasi karyawan (Idrus, 2006). Hardjana (2013) bahkan menambahkan kondusifnya iklim kerja dapat mengambarkan 'lingkungan kerja manusiawi' atau tidak, sehingga dapat meningkatkan kepuasan kerja. Beberapa penelitian sebelumnya juga menunjukkan hubungan antara iklim organisasi dengan kepuasan kerja(Etty Susanty, 2012; Liana, 2012; Runtu \& Widyarini, 2009).

Sementara itu penelitian lainnya juga menjelaskan bagaimana hubungan antara perceived organizational support terhadap kepuasan kerja (Azhar, 2019; Puspaatmaja \& Aryana Satrya, 2016; Sandra et al., 2015). Perceived organizational support yang positif dari perusahaan akan menciptakan kepuasan kerja yang positif pula bagi karyawan (Puspaatmaja \& Aryana Satrya, 2016; Rooswita Santia, 2015). Perceived organizational support karyawan yang tinggi semakin dapat memprediksi kepuasan kerja karyawan dengan baik. Sumbangan efektif dari 75,8\% menjadi 97,9\%. Artinya variabel moderator memberikan andil sebesar $22 \%$ dan memiliki dampak pada peningkatan kepuasan kerja karyawan.

\section{SIMPULAN}

Berdasarkan hasilpenelitian yang telah dilakukan, dapat disimpulkan bahwa ternyata perceived organizational support yang dirasakan karyawan sebagai moderator pengaruh iklim organisasi terhadap kepuasan kerja karyawan sudah tepat dalam model ini. Perceived organizational support berpengaruh signifikan terhadap iklim organisasi dalam meningkatkan kepuasan kerja karyawan.Namun, berdasarkan dari hasil analisis yang ada menunjukkan bahwa antara Iklim Organisasi dan Perceived Organizational Support relatif memiliki kesamaan, sehingga dapat dipahami antara variabel tersebut sudah tampak saling menguatkan dikarenakan memiliki kesamaan atau kurang varian.

\section{DAFTAR PUSTAKA}

Ariyani, E. D. (2012). Dampak Iklim Organisasi terhadap Kepuasan Kerja (Studi pada Karyawan Tetap di Polman Bandung). Jurnal Manajerial, 11(21), 68-80.

Azhar. (2019). Pengaruh perceived organizational support dan kepuasan kerja terhadap organizational citizenship behavior ( ocb ) dengan komitmen organisasi sebagai variabel mediator Effect of perceptions of organizational support and job satisfaction towards organizational. Akuntabel, 16(1), 36-46.

Davis, K. (2001). Organizational Behavior. New york: Mc Graw Hill Book.

Dirks, K. T., \& Ferrin, D. L. (2002). Trust in leadership: Meta-analytic findings and implications for research and practice. Journal of Applied Psychology, 87(4), 611-628. https://doi.org/10.1037/0021-9010.87.4.611

Etty Susanty. (2012). Pengaruh iklim organisasi terhadap kepuasan kerja dan komitmen karyawan pada universitas terbuka. Jurnal Organisasi Dan Manajemen, 8, 121-134.

Gershon, R. R. M., Stone, P. W., Zeltser, M., Faucett, J., Macdavitt, K., \& Chou, S. S. (2007). Organizational climate and nurse health outcomes in the United States: A systematic review. Industrial Health, 45(5), 622-636. https://doi.org/10.2486/indhealth.45.622

Hardjana, A. (2013). Iklim Organisasi: Lingkungan Kerja Manusiawi. Jurnal ILMU KOMUNIKASI, 3(1), 1-35. https://doi.org/10.24002/jik.v3i1.238 
Idrus, M. (2006). Implikasi Iklim Organisasi Terhadap Kepuasan Kerja Dan Kualitas Kehidupan Kerja Karyawan. Jurnal Psikologi Undip, 3(1), 94-106. https://doi.org/10.14710/jpu.3.1.94

Lagonah, S., Pio, R., \& Kaunang, M. (2013). Pengaruh Iklim Organisasi Dan Budaya Organisasi Terhadap Kepuasan Kerja Pegawai Kantor Pertanahan Kota Manado. Journal of Chemical Information and Modeling, 53(9), 1689-1699. https://doi.org/10.1017/CBO9781107415324.004

Liana, Y. (2012). Iklim Organisasi Dan Motivasi Berperstasi Terhadap Kepuasan Kerja Dan Kinerja Guru. Jurnal Manajemen Dan Akuntansi, 1(2), 15-30.

Nurendra, A. M., \& Mega Putri Saraswati. (2018). Model Peranan Work life balance, stress kerja dan kepuasan kerja pada karyawan. Humanitas, 13(2), 84-94. https://doi.org/10.1017/CBO9781107415324.004

Puspaatmaja, S., \& Aryana Satrya. (2016). analisis pengaruh perceived organizational support sebagai mediator antara partisipasi karyawan dalam pengambilan keputusan terhadap kepuasan kerja dan komitmen afektif karyawan non manajerial di perusahaan fmcg indonesia. Jurnal Manajemen Dan Bisnis Sriwijaya, 14(4), 5-9.

R.Yudhi Satria R.A. (2005). Hubungan Antara Komitmen Organisasi dan Iklim Organisasi dengan Kepuasan Kerja Karyawan Universitas Muhammadiyah Surakarta. Jurnal Benefit, 9(2), $123 . \quad$ Retrieved from http://journals.ums.ac.id/index.php/benefit/article/viewFile/1216/780

Robbins, S. P. (2003). Perilaku Organisasi (9th ed). Jakarta: PT Indeks.

Robbins, S. P., \& Timothy A. Judge. (2014). Perilaku Organisasi. Jakarta: Salemba Empat.

Rooswita Santia. (2015). Peranan Perceived Organizational Support Terhadap Kepuasan Kerja Role of Perceived Organizational Support Toward Job Satisfaction. Ecopsy, 2(3).

Runtu, D., \& Widyarini, M. (2009). Iklim Organisasi, Stres Kerja, Dan Kepuasan Kerja Pada Perawat. Jurnal Ilmiah Psikologi Gunadarma, 2(2), 150.

Sandra, G., Alfian, A., \& N, Z. (2015). Pengaruh Budaya Organisasi Dan Perceived organizational support Terhadap Komitmen Karyawan. Jurnal Psikologi TALENTA, 1(1), 15. https://doi.org/10.26858/talenta.v1i1.5223

Saputra, M., \& Rahardjo, W. (2013). Pengaruh Iklim Organisasi, Kepuasan Kerja, Keterlibatan Kerja Terhadap KOmitmen Organisasi Pada Karyawan PT. X. Jurnal Psikologi, 16(1), 117.

Surachim, A. (2008). Pengaruh Iklim Organisasi Terhadap Kepuasan Kerja Karyawan Pada Divisi Pharmaserve Di Pt Combiphar Jakarta. Strategic: Jurnal Pendidikan Manajemen Bisnis, 8(1), 58. https://doi.org/10.17509/strategic.v8i1.1005

Wibisono, A. (2011). Pengaruh iklim organisasi terhadap kepuasan kerja (studi tentang pengaruh iklim organisasi terhadap kepuasan kerja pegawai puskesmas Turen di Malang). Jurnal Aplikasi Manajemen, 9(3). 